\title{
SIZING OPTIMIZATION OF A PHOTOVOLTAIC/BATTERY SYSTEM BASED ON ANALYSIS OF THE ANNUAL TOTAL SOLAR RADIATION IN THE NORTH OF VIETNAM
}

\author{
Nguyen Thi Hoai Thu \\ Hanoi University of Science and Technology
}

\begin{abstract}
This paper proposed a novel method for optimal capacity designing of photovoltaic (PV) system combined with battery supplying to 2 types of load pattern in the North of Vietnam. The optimization problem is to minimize the levelized cost of energy (LCE) and satisfy the required grid dependency (GD). Generally, GD was estimated based on the time series of weather data. In this research, we developed an empirical formula of the GD. The GD was simulated using the meteorological data over the past 15 years in 7 locations in the North of Vietnam. From the results, the GD could be estimated based on the annual total solar radiation, the capacity of PV and battery without consideration of the time series of the weather data. After obtaining the empirical formula, the optimal configuration of the PV/battery system was calculated. The developed formula can lead to the simplicity in process of sizing optimization. Additionally, the sensitivity analysis was also conducted to investigate the results when the price of PV and battery changes. The results show that the proposed method is highly accurate and can be applied to any location in the North, especially with incomplete weather data.
\end{abstract}

Keywords: Sizing optimization; photovoltaic system; battery; grid dependency; annual total radiation

Received: 25/6/2020; Revised: 24/8/2020; Published: 31/8/2020

\section{TÍNH TOÁN DUNG LƯợNG TỐI ƯU CHO HÊ THỐNG PIN MẠT TRÒ̀I/ ĂC QƯY TẠI MIỀN BĂC VIÊTT NAM DỰA TRÊN PHÂN TÍCCH TỐNG LƯợNG BỨC XẠ HÀNG NĂM}

\author{
Nguyễn Thị Hoài Thu \\ Truoòng Đại học Bách Khoa Hà Nội
}

\section{TÓM TẮT}

Bài báo này đưa ra 1 phương pháp để xác định dung lượng tối ưu của hệ thống pin mặt trời kết hợp ắc quy cung cấp điện cho 4 loại tải hộ gia đình và văn phòng ở khu vực miền Bắc Việt Nam. Bài toán được xây dựng với hàm mục tiêu là tối thiểu chi phí tính toán hàng năm (LCE) và ràng buộc về độ phụ thuộc vào lưới (GD) theo yêu cầu cho trước. Thông thường GD phụ thuộc vào chuỗi số liệu thời tiết của bức xạ mặt trời. Tuy nhiên nghiên cứu này đã xây dựng công thức ước lượng GD là hàm số của tổng lượng bức xạ hàng năm, dung lượng của battery và $\mathrm{PV}$ sử dụng số liệu thời tiết trong 15 năm của 7 tỉnh miền Bắc Việt Nam. Từ đó có thể sử dụng phương pháp lặp để tìm cấu hình tối ưu của hệ thống tương ứng với GD yêu cầu một cách đơn giản. Ngoài ra, nghiên cứu cũng tiến hành phân tích độ nhạy khi chi phí của hệ thống pin mặt trời và ắc quy thay đổi. Các kết quả tính toán cho thấy phương pháp đề xuất có độ chính xác cao và có khả năng áp dụng với những khu vực khác ở miền Bắc khi không có số liệu thời tiết đầy đủ.

Từ khóa: dung luợng tối uu; hệ thống điện mặt trời; battery; độ phụ thuộc lưới; tổng luợng bức xạ hàng năm

Ngày nhận bài: 25/6/2020; Ngày hoàn thiện: 24/8/2020; Ngày đăng: 31/8/2020

Email: thu.nguyenthihoai@hust.edu.vn https://doi.org/10.34238/tnu-jst.3367 


\section{Introduction}

The increasing energy demand, the global warming issues as well as the energy crisis promotes the use of renewable energy sources all over the world [1]. However, along with the advantages, there are some drawbacks associated with renewable energy (RE) including their unpredictable nature, their intermittency and fluctuation depending on the weather. Battery is one of the possible solutions to these obstacles because of its advantage of its fast dynamic characteristics and high round - trip efficiency [2].

Designing the system capacity plays an important role for enhancing RE applications due to the high cost of the system. Oversizing of the RE system can lead to the reliability as well as the economic issues. There are various approaches for determining the optimal sizing of the system reported in literatures, such as dynamic programming [3], graphic construction technique [4], linear programming, probabilistic approaches [5], iterative methods [6], and artificial intelligent methods [7]. In [6], Yang et al. proposed an iterative method to solve the optimization problem for a hybrid solar - wind system based on Hybrid Solar-Wind System Optimization Sizing model, which included 3 parts: the model of the hybrid system, the model of Loss of Power Supply Probability (LPSP) and the model of the Levelized Cost of Energy (LCE). Using iterative procedure, several possible combinations of solar - wind generation capacities that satisfied the requirement of LPSP were obtained. For each configuration, the LCE is then calculated and the configuration with the lowest cost is considered as the optimal one.

However, the system capacity was designed using the weather data of typical year. The simulation needs to perform for at least decades of year due to the changing of the weather. In our previous study [8], the empirical formulas for calculating the grid dependency of a PV/battery system in the North of Vietnam supplying to several kinds of load patterns were developed. This paper focuses on the optimal sizing of the PV/battery system using iterative method and the formulas of the GD depending on the total annual solar irradiation and the devices capacity.

\section{Sizing formulation}

Figure 1 shows the RE system under study. The PV arrays are connected with a battery supplying power to the load through a DC network. The PV panels are connected to a DC bus through a power conditioner (PCS) while the others are connected to DC bus by converter/inverter. The use of DC bus is popular in the RE generation based microgrid due to its advantages over AC energy distribution [9].

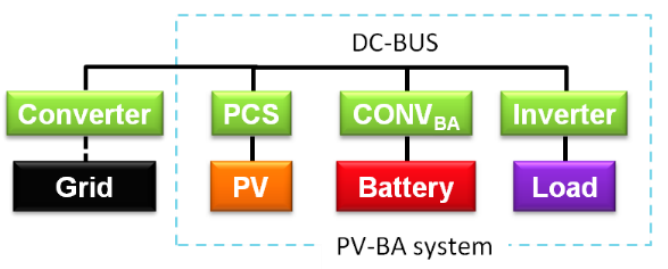

Figure 1. The PV/Battery system

\subsection{System modeling}

The PV module is comprised of solar cells that convert solar energy to electricity [Optimization of a hybrid system for solarwind-based water desalination by reverse osmosis: Comparison of approaches]. The PV output power mainly depends on the solar irradiance and the temperature. It can be modeled as [8]:

$$
\begin{gathered}
P_{\mathrm{PV}}(t)=C_{\mathrm{PV}} \times \frac{S(t)}{\mathrm{S}_{\mathrm{STD}}} \times \eta_{\mathrm{loss}}(t) \times \eta_{D C / D C}^{P V} \\
\eta_{\mathrm{loss}}(t)=1-\lambda\left(T_{\text {cell }}(t)-25\right) \\
T_{\text {cell }}(t)=T_{\mathrm{a}}(t) \times \frac{S(t)}{0.8} \times\left(\mathrm{T}_{\mathrm{NOCT}}-20\right)
\end{gathered}
$$

where $P_{P V}(t), C_{P V}$ are the output power and the rated power of $\mathrm{PV}(\mathrm{kW})$, respectively. $\mathrm{S}(\mathrm{t}), \mathrm{S}_{\mathrm{STD}}$ are the real solar irradiance at the tilted surface of $\mathrm{PV}$ panels $\left(\mathrm{kW} / \mathrm{m}^{2}\right)$ and the standard solar irradiance $\left(1 \mathrm{~kW} / \mathrm{m}^{2}\right)$, 
respectively. $\eta_{D C / D C}^{P V}$ is the efficiency of the DC/DC converter. $\eta_{\text {loss }}(t)$ is the efficiency standing for the loss due to the temperature increase. $\lambda$ stands for the temperature coefficient $\left(0.00485 /{ }^{\circ} \mathrm{C}\right) . \mathrm{T}_{\text {cell }}(\mathrm{t}), \mathrm{T}_{\mathrm{a}}(\mathrm{t})$ and $\mathrm{T}_{\text {NOCT }}$ are the temperature of the $\mathrm{PV}$ cell, the ambient temperature $\left({ }^{\circ} \mathrm{C}\right)$ and the nominal operating cell temperature $\left(45^{\circ} \mathrm{C}\right)$, respectively.

In this paper, we used the model of solar irradiance on the tilted surface that was described in detail in detail in [9]. The model includes 3 components: the direct beam, diffuse radiation and reflected light.

Battery is a device which can be used in the renewable energy system to compensate the fluctuation and to work as a short-term storage [8]. Besides the advantages of fast charging/discharging capacity and high round - trip efficiency, battery also has low energy density, self-discharge and leakage. Battery will charge the surplus power and discharge the shortage power (Eq. 4, 5). The energy in battery can be estimated using equation 6 .

$$
\begin{aligned}
& P_{\mathrm{DCSide}}^{\mathrm{BA}}(t)=P_{\mathrm{PV}}(t)-\frac{P_{D}(t)}{\eta_{\mathrm{INV}}} \\
& P_{\mathrm{DCSide}}^{\text {BA.disch }}(t)=\frac{P_{D}(t)}{\eta_{\mathrm{INV}}}-P_{\mathrm{PV}}(t) \\
& E_{\mathrm{BA}}(t)=E_{\mathrm{BA}}(t-1) \times(1-\sigma)+ \\
& \left(P_{\mathrm{DC} \text { side }}^{\mathrm{BA} . \mathrm{ch}}(t-1) \times \eta^{\text {ch }} \times \eta_{C O N V}-\frac{P_{\mathrm{DCCide}}^{\mathrm{B} . \mathrm{isch}}(t-1)}{\eta^{\text {disch }} \times \eta_{C O N V}}\right) \times \Delta t
\end{aligned}
$$

where $\mathrm{E}_{\mathrm{BA}}(\mathrm{t})$ is the energy in the battery at

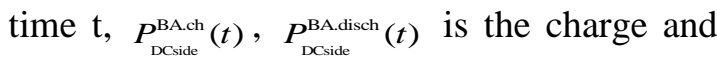
discharge power allocated to the battery at DC bus side of DC/DC converter, $\sigma$ is the selfdischarge rate of the battery $(0.0046 /$ day $=$ $0.0046 / 24 \mathrm{~h}), \Delta \mathrm{t}$ is time step $(1 \mathrm{~h}) . \eta^{\mathrm{ch}}$ and $\eta^{\text {disch }}$ are the efficiencies of the charge and discharge process, respectively $(0.9), \eta^{\mathrm{INV}} \eta^{\mathrm{CONV}}$ are the inverter/converter efficiency (0.9).

When battery is deeply discharged, the insufficient power will be supplied from the grid and can be calculated as below:

$$
P_{\text {grid }}(t)=\frac{P_{D}(t)}{\eta_{\mathrm{INV}}}-P_{\mathrm{PV}}(t)-P_{D C \text { side }}^{B A \text { disch }}(t)
$$

In case of fully charged battery, the surplus energy will be dumped.

The system was to supply to 2 load profiles, that are household, office load which are shown in Figure 2.

\subsection{Optimization problem}

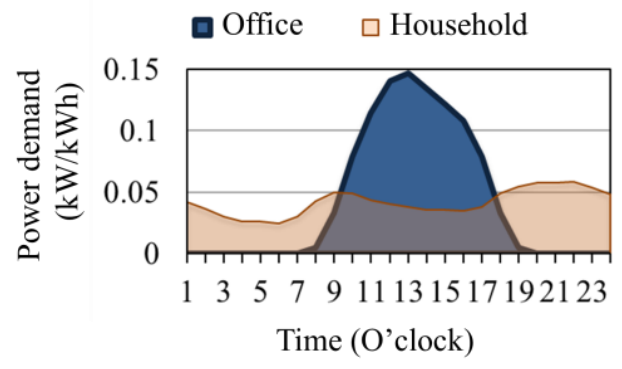

Figure 2. Load pattern for office and domestic household The objective of the problem is to determine the optimal capacity of PV panel and battery in order to minimize the levelized cost of energy (LCE).

$\min \mathrm{LCE}=\min \mathrm{f}\left(\mathrm{C}_{\mathrm{PV}}, \mathrm{C}_{\mathrm{BA}}\right)$

LCE is defined as the constant price per unit of energy and calculated as the below equation:

$$
\begin{gathered}
\mathrm{LCE}=\frac{\mathrm{C}_{\mathrm{TA}}}{\mathrm{E}_{\text {Dyear }}} \\
\text { where } \mathrm{C}_{\mathrm{TA}}=\mathrm{C}_{\mathrm{AC}}+\mathrm{C}_{\mathrm{AOM}}+\mathrm{C}_{\mathrm{AEP}} \\
\mathrm{C}_{\mathrm{AC}}=\left(\mathrm{C}_{\text {equip }}+\mathrm{C}_{\text {aux }}\right) \times \mathrm{CRF} \\
\mathrm{CRF}=\frac{\mathrm{j}(1+\mathrm{j})^{\mathrm{n}}}{(1+\mathrm{j})^{\mathrm{n}}-1} \\
\mathrm{C}_{\text {equip }}=\mathrm{k}_{\mathrm{PV}} \times \mathrm{C}_{\mathrm{PV}}+\mathrm{k}_{\mathrm{BA}} \times \mathrm{C}_{\mathrm{BA}} \times \sum_{\mathrm{n}=0}^{\mathrm{y}_{\mathrm{B}}} \frac{1}{(1+\mathrm{i})^{\mathrm{n} \times \mathrm{L}_{\mathrm{BA}}}} \\
+\mathrm{k}_{\mathrm{DC} \mathrm{IDC}} \times\left(\mathrm{C}_{\mathrm{PV}}+\mathrm{C}_{\mathrm{BA}}\right) \times \sum_{\mathrm{j}=0}^{\mathrm{y}_{\mathrm{pCDC}}} \frac{1}{(1+\mathrm{i})^{\mathrm{j} \times \mathrm{L}_{\mathrm{DCDC}}}} \\
\mathrm{C}_{\text {aux }}=\mathrm{C}_{\text {equip }} \times \mathrm{r}_{\text {aux }} \\
\mathrm{C}_{\mathrm{AOM}}=\left(\mathrm{C}_{\text {equip }}+\mathrm{C}_{\text {aux }}\right) \times \mathrm{r}_{\mathrm{OM}} \\
\mathrm{C}_{\mathrm{AEP}}=\Delta \mathrm{E}_{\mathrm{EP}} \times \mathrm{k}_{\mathrm{EP}}=\sum_{\mathrm{t}=1}^{8760}\left(\mathrm{P}_{\text {grid }}(\mathrm{t}) \times 1\right) \times \mathrm{k}_{\mathrm{EP}}
\end{gathered}
$$

where $\mathrm{C}_{\mathrm{TA}}$ is the total annual cost of the system. $\mathrm{C}_{\mathrm{AC}}$ is the annual cost for the 
equipment which includes the capital cost of the main and the auxiliary equipment, $\mathrm{C}_{\mathrm{AOM}}$, $\mathrm{C}_{\mathrm{AEP}}$ are the annual cost of operation and maintenance, the annual cost for purchasing the electricity from the grid. CRF is the capital recovery factor. $\mathrm{i}$ is the interest rate, $\mathrm{N}$ is the project lifetime. $\mathrm{k}_{P V}, \mathrm{k}_{\mathrm{BA}}, \mathrm{k}_{\mathrm{DC} / \mathrm{DC}}$ represent the unit price, $\mathrm{C}_{\mathrm{PV}}, \mathrm{C}_{\mathrm{BA}}$ are the capacity of the devices, respectively. $r_{a u x}$ is the ratio of the auxiliary equipment cost to the main equipment cost, $\mathrm{r}_{\mathrm{OM}}$ is the ratio of the operation and maintenance cost to the equipment cost. $\mathrm{L}_{\mathrm{BA}}, \mathrm{L}_{\mathrm{DC} / \mathrm{DC}}$ are the lifetime of the battery and DC/DC. $\mathrm{y}_{\mathrm{BA}}, \mathrm{y}_{\mathrm{DC} / \mathrm{DC}}$ are the number of replacements of these during the project lifetime.

The objective is subject to the following constraints of the required grid dependency:

$$
\mathrm{GD} \leq \mathrm{GD}_{\text {req }}
$$

Grid dependency is the ratio of the total energy purchasing from the grid to the demand energy in one year.

$$
\mathrm{GD}=\frac{\sum_{\mathrm{t}=1}^{8760}\left(\mathrm{P}_{\text {grid }}(\mathrm{t}) \times 1\right)}{\mathrm{E}_{\text {Dyear }}}
$$

The above equation expresses the power equality of the system. In addition, there is also the constraint of the energy in battery. The algorithm to calculate the GD based on the time series of the weather data was described in detail in [8].

\section{Methodology}

Because of the intermittency of the PV power output, the GD of a PV system is commonly calculated using time series data. Therefore, the conventional capacity designing methods is based on an iterative method with the combination of the PV/ battery capacity and the time series of weather data. The calculation will be too enormous if all lifetime time series of weather conditions are taken into account. In addition, when the data is not available for several days or months, the calculation will be difficult or inaccurate.

In this paper, we proposed a new designing method based on the analysis of the annual total irradiation. Firstly, we developed an empirical formula of GD depending on and the devices capacity. GD was calculated using hourly time series data of solar irradiation and temperature during 15 years in 7 locations in the North of Vietnam to create a database for analyzing the relationship between GD and other parameters. Secondly, after developing the empirical of GD, we can obtain the optimal capacity of PV/battery system in a simpler way using iterative method.

\subsection{Development of GD formula}

As mentioned above, the proposed designing method will be based on the formula of GD depending on the PV/battery capacity and the weather conditions. Therefore, in this part, we analyze the relationship of GD and those parameters, namely the annual total radiation $S_{\text {total, }}$ the capacity of $\mathrm{PV}$ and battery $\mathrm{C}_{\mathrm{PV}}, \mathrm{C}_{\mathrm{BA}}$, based on the $\mathrm{GD}$ calculating from the real data of temperature and solar irradiance of 7 provinces (Son La, Quang Ninh, Hai Phong, Ha Noi, Nghe An, Da Nang and Hue) in the North of Vietnam during 15 years combined with different capacities of PV/battery system. Figure 3 shows the example of the solar radiation and temperature in Hanoi in 2003.

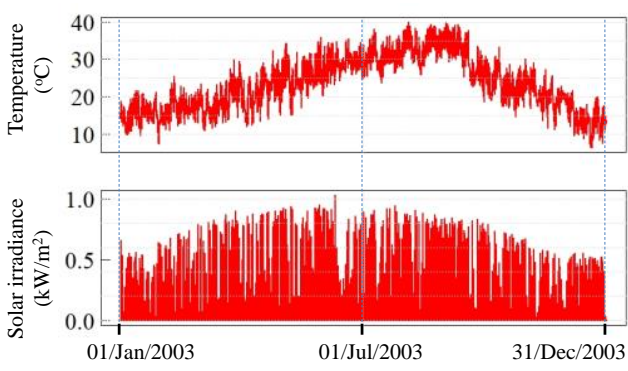

Figure 3. Solar irradiation and temperature in Hanoi in 2003 


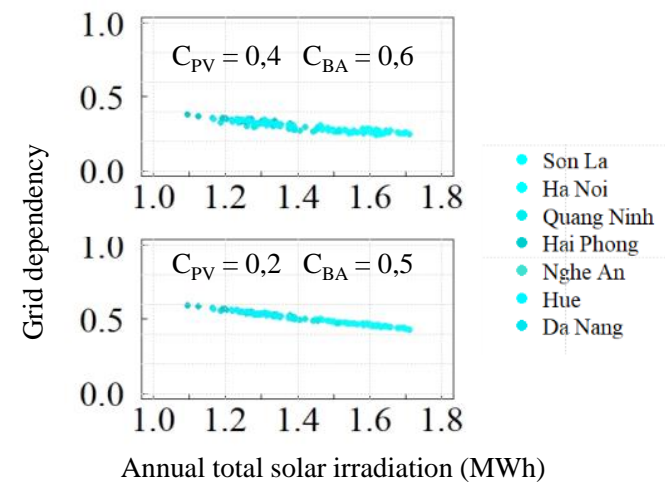

Figure 4. The dependence of GD on the annual total irradiation

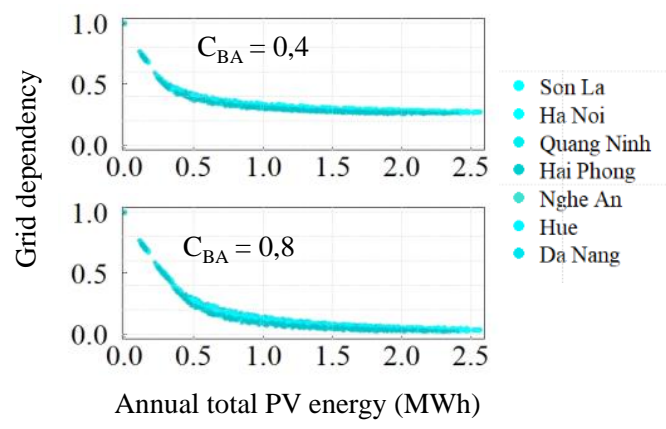

Figure 5. The dependence of GD on the annual $P V$ energy

The regression model was used to develop the relationship of GD and $\mathrm{S}_{\text {total }}, \mathrm{C}_{\mathrm{PV}}, \mathrm{C}_{\mathrm{BA}}$. First, we fit the dependence on 1 variable, and then each regressive coefficient was derived from the left variables. The coefficient of determination $\mathrm{R}^{2}$ was used to evaluate the accuracy of the fitting. The closer to 1 the coefficient of determination is, the higher the accuracy is.

The relationship between GD and $S_{\text {total }}$ was shown in Figure 4. It can be seen that GD is approximately linear with the annual total radiation $S_{\text {total }}$ regardless of which year and location. The significantly high correlation of GD and $\mathrm{S}_{\text {total }}$ leads to the fact that the GD can be estimated using $\mathrm{S}_{\text {total }}$ without consideration of time series of weather data as well as the region.

Based on the finding of the linear relationship of GD and the annual total irradiation $S_{\text {total }}$, the GD is expectedly dependent on the annual PV power generation $\mathrm{E}_{\mathrm{PV}}$ as the following equation:

$$
E_{P V}=S_{\text {total }} \times C_{P V}=\left(\sum_{t=1}^{8760} S(t) \cdot \Delta t\right) \times C_{P V}
$$

Figure 5 depicts this relationship in several case of $\mathrm{C}_{\mathrm{BA}}$. From the results, it is clearly seen that all the points distributed on an exponential curve.

$$
G D=a \times e^{k E_{P V}}+1-a
$$

in which $\mathrm{a}, \mathrm{k}$ are the regressive coefficients.

These regressive coefficients are fitted as functions of $\mathrm{C}_{\mathrm{BA}}$ using the least square method as following regression equations:

$$
\begin{gathered}
a= \begin{cases}a_{1} \times C_{B A}+a_{2} & \left(C_{B A}<C_{1}\right) \\
a_{3} \times e^{a_{4} C_{B A}}+a_{5} & \left(C_{1} \leq C_{B A}\right)\end{cases} \\
k= \begin{cases}k_{1} \times C_{B A}+k_{2} & \left(C_{B A}<\mathrm{C}_{2}\right) \\
k_{3} \times C_{B A}^{2}+k_{4} \times C_{B A}+k_{5} & \left(\mathrm{C}_{2} \leq C_{B A}<\mathrm{C}_{3}\right) \\
k_{6} \times C_{B A}+k_{7} & \left(\mathrm{C}_{3} \leq C_{B A}\right)\end{cases}
\end{gathered}
$$

The value of these coefficients was described in Table 1.

Although each fitting step has high accuracy, the 2-step formula establishment may result in significantly error. Therefore, we evaluated the final formula by the mean absolute error (MAE). The result shows that MAE for all the formula of all the patterns is generally of 0.04 , a reasonably small value meaning that the obtained formulas are considerably accurate and can be applied to estimate GD.

Table 1. The coefficient of empirical formula of GD corresponding to each load pattern

\begin{tabular}{cccccc}
\hline Load & $\mathbf{C}_{1}$ & $\mathbf{C}_{2}$ & $\mathbf{C}_{3}$ & $\mathbf{a}_{1}$ & $\mathbf{a} 2$ \\
\hline 1 & 0.2 & 0.12 & 0.9 & 0.303 & 0.908 \\
2 & 0.6 & 0.16 & 1 & 0.710 & 0.427 \\
& $\mathrm{a}_{3}$ & $\mathrm{a} 4$ & $\mathrm{a}_{5}$ & $\mathrm{k}_{1}$ & $\mathrm{k}_{2}$ \\
1 & -0.08 & -2.05 & 1.017 & -0.93 & -2.95 \\
2 & -2.108 & -4.369 & 1.009 & 3.429 & -5.277 \\
& $\mathrm{k}_{3}$ & $\mathrm{k}_{4}$ & $\mathrm{k}_{5}$ & $\mathrm{k}_{6}$ & $\mathrm{k}_{7}$ \\
1 & 0.076 & -0.225 & -3.015 & -0.073 & -3.098 \\
2 & -3.249 & 6.094 & -5.558 & -0.037 & -2.691 \\
\hline
\end{tabular}

\subsection{Selection of $S_{\text {total }}$}

In order to estimate the GD by the formula, which value of $S_{\text {total }}$ should be selected. In this part, we estimate the GD for a PV/battery system which includes a $2 \mathrm{~kW}-\mathrm{PV}$, a $3 \mathrm{kWh}$ battery supplying to household that uses 10 
$\mathrm{kWh} /$ day in Thanh Hoa, Vietnam in 2 ways. The GD was calculated using the irradiation time series in 20 years and then compared with the GD estimated by the formula developed in the subsection 3.1.

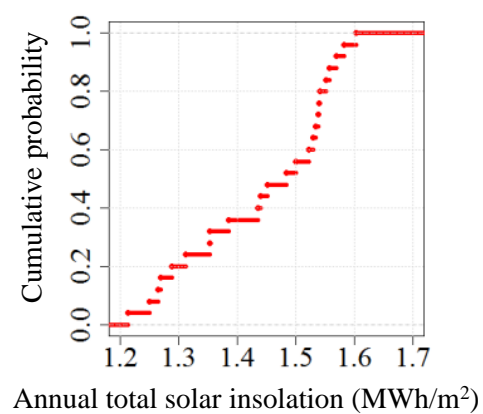

Figure 6. The cumulative probability of the $S_{\text {total }}$

Figure 6 shows the cumulative probability of the $\mathrm{S}_{\text {total }}$ in Thanh Hoa. The comparison of GD in 2 ways was also carried out. The GD which was determined by conventional method ranges from 0.538 to 0.598 , approximately similar to the values of GD calculated by the developed formula.

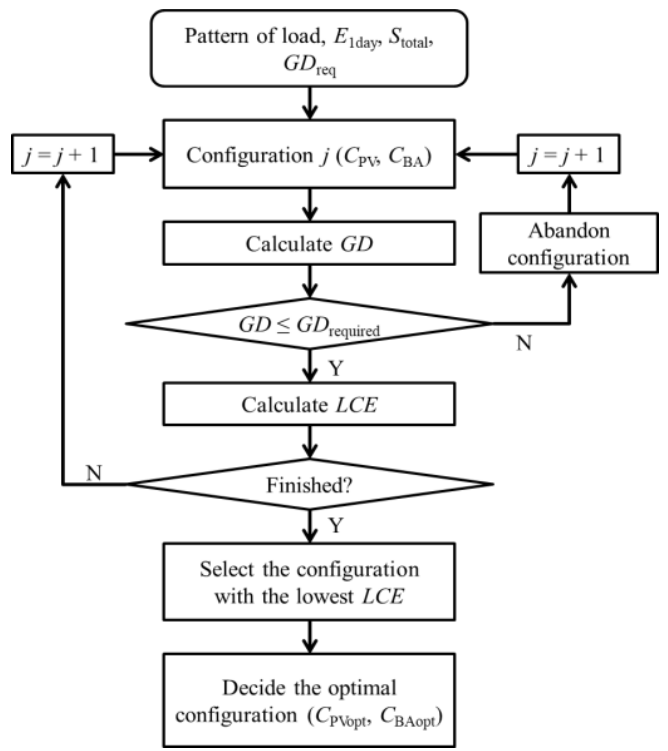

Figure 7. Algorithm to select the optimal configuration corresponding to $G D_{\text {req }}$ based on the developed formula

In addition, aiming at estimating the GD by the formula, it is necessary to choose the $S_{\text {total }}$. It can be realized that GD is inversely proportional to the $S_{\text {total }}$. Then selecting large $S_{\text {total }}$ will result in small GD, which means the estimated grid dependence may be less than the actual one. Thus, the selected $S_{\text {total }}$ needs to be reasonably small to avoid unexpectedly small GD. Based on the cumulative probability of the $S_{\text {total }}$ in Figure 6, the GD can be calculated corresponding to different cumulative $S_{\text {total. }}$. By comparison those values, it was found that the $S_{\text {total }}$ with respect to the so - called "guaranteed probability of $95 \%$ ", e.g. $S_{\text {total }}^{95 \%}(1.253)$, results in the GD of 0.594 similar to the maximum real GD. This indicates that we can use $S_{\text {total }}^{95 \%}$ to estimate the GD through the developed formula.

\subsection{Designing method}

In the previous subsections, we developed the empirical formula of GD which depends on the $S_{\text {total }}$ as well as the device capacity. Based on this formula, we can design the PV/battery system simply. The algorithm of the proposed method is shown in Figure 7. The input data includes the actual load profile, $\mathrm{E}_{1 \text { day }}, \mathrm{S}_{\text {total }}^{95 \%}$ and the $\mathrm{GD}_{\text {required. }}$ Firstly, select the formula of GD corresponding to the load pattern which is the most similar with the actual load. Then, using the $\mathrm{S}_{\text {total }}^{95 \%}$, the capacity $\left(\mathrm{C}_{\mathrm{BA}} *\right.$, $\mathrm{C}_{\mathrm{PV}^{*}}$ ), calculate GD and LCE and check the requirement of GD. Change the configurations and repeat the process until all the configurations in the considered range are evaluated. The configuration that satisfies the required GD and has the lowest LCE will be the optimal configuration.

It is noted that we assumed obtained optimal sizing $\left(\mathrm{C}_{\mathrm{BAopt}}{ }^{*}, \mathrm{C}_{\mathrm{PVopt}}{ }^{*}\right)$ is corresponding to the load energy of $1 \mathrm{kWh} /$ day. Therefore, the optimal capacity of PV and battery will be determined as below:

$$
C_{\mathrm{BAopt}}=C_{\mathrm{BAopt}}^{*} \times E_{\text {lday }}, C_{\mathrm{PV} \text { opt }}=C_{\mathrm{PV} \text { opt }}^{*} \times E_{\text {lday }}
$$

\section{Optimization result}

The proposed sizing method was applied to design the PV/battery system supplying to a household in Thanh Hoa which is supposed to 
consume $1 \mathrm{kWh} /$ day. The $\mathrm{S}_{\text {total }}^{95 \%}$ was determined of $1,253 \mathrm{MWh} / \mathrm{m}^{2}$. The economic parameters was listed in Table 2.

Table 2. The economic parameters

\begin{tabular}{ccccc}
\hline $\mathbf{k P V}$ & $\mathbf{k}_{\mathbf{B A}}$ & $\mathbf{k}_{\mathbf{D C} / \mathbf{D C}}$ & $\mathbf{n}$ & $\mathbf{j}$ \\
\hline $312 / 0.26$ & $170 / 2.1$ & $751 / 2$ & 20 & 0.08 \\
$\$ / \mathrm{kW}$ & $\$ / \mathrm{kWh}$ & $\$ / \mathrm{kW}$ & years & \\
yDC/DC & $\mathbf{y}_{\mathbf{B A}}$ & $\mathbf{r}_{\text {aux }}$ & $\mathbf{r}_{\mathbf{m}}$ & $\mathbf{k}$ \\
10 years & 4 years & $10 \%$ & $1 \%$ & $0.1 \$ / \mathrm{kWh}$ \\
\hline
\end{tabular}

The optimal configurations corresponding to several GD req was shown in Table 3. Corresponding to each $\mathrm{GD}_{\text {req, }}$, we can find out the optimal PV/battery sizing with the minimum $\mathrm{LCE}\left(\mathrm{LCE}_{\mathrm{min}}\right)$. In the case of the value of $\mathrm{GD}_{\text {req }}$ is 0 , the $\mathrm{LCE}_{\min }$ is $1.229 \$ / \mathrm{kWh}, 12$ times of the electrical price by purchasing from the grid. On the other hand, when the $\mathrm{GD}_{\text {req }}$ is of 1 meaning the system completely depends on the grid then the LCE is $0.1 \$ / \mathrm{kWh}$ which result is suitable.

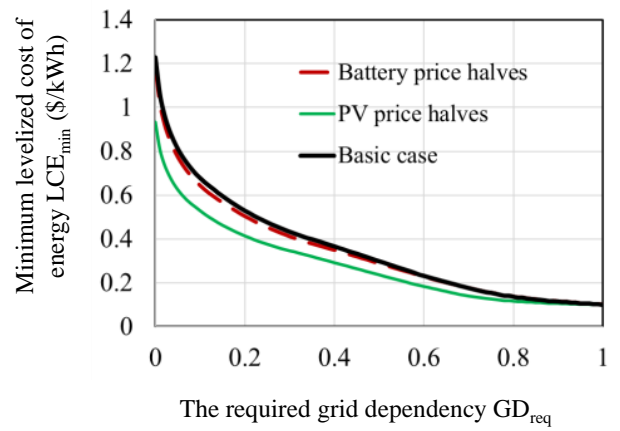

Figure 8. The dependence of GD on the annual $P V$ energy

In addition, sensitivity analysis when the PV/battery price changes were also carried out. Fig.8 compares the change of $\mathrm{LCE}_{\min }$ corresponding to different $\mathrm{GD}_{\text {req }}$ in the basic case and the case of PV/battery price halve. The corresponding optimal sizing of PV system and battery were shown in Table 2 . It can be realized that when the price of battery decreases, the system will be optimal using battery with high capacity if $\mathrm{GD}_{\text {req }}$ is low. However, if $\mathrm{GD}_{\text {req }}$ is higher, about 0.04 and above, then the optimal configuration is unchanged. This can be explained that when the battery capacity is large enough, its value has insignificant effect on the GD. Therefore, when the $\mathrm{GD}_{\text {req }}$ is high, meanwhile, if the PV price reduces, the system will be economic when using large PV capacity.

However, the proposed one can obtain an acceptable optimal capacity and especially, it is a very simple method to solve the optimization problem of PV/battery system.

\section{Conclusion}

In this work, the empirical formula of GD of a PV/battery system depending on the annual total insolation and the system capacity was developed corresponding to two types of load patterns in the North of Vietnam. The GD is found to be linearly proportional to the Based on the developed formula; we can estimate the GD in a simple and accurate way without using the time series of weather data again, especially for the area in the North of Vietnam where the data is unavailable or insufficient. Then, the optimal sizing of the system can be calculated using simple iterative algorithm by minimizing the levelized cost of energy while the GD was guaranteed as required. Additionally, the analysis on the sensitivity was conducted to investigate the change of LCE and optimum configuration when some parameters like the PV/battery decrease. The results show that corresponding to these decreases, the optimal sizing is nearly unchanged with low GD and slightly changed with high GD. In conclusion, the proposed method is not only simple but also considerably accurate and can be applied to design the PV/battery system developed in the North of Vietnam, especially for the area in the North of Vietnam where the data is unavailable or insufficient. 
Table 3. Optimal sizing of the PV/battery system supplying to a household of $5 \mathrm{kWh} /$ day in Thanh Hoa for different cases of $P v /$ battery price

\begin{tabular}{cccccccccc}
\hline & \multicolumn{3}{c}{ The main case } & \multicolumn{3}{c}{ The price of battery halves } & \multicolumn{3}{c}{ The price of PV halves } \\
\hline $\mathrm{GD}_{\text {req }}$ & $\mathrm{C}_{\text {pvopt }}$ & $\mathrm{C}_{\text {ba.opt }}$ & $\mathrm{LCE}_{\min }$ & $\mathrm{C}_{\text {pv.opt }}$ & $\mathrm{C}_{\text {ba.opt }}$ & $\mathrm{LCE}_{\min }$ & $\mathrm{C}_{\text {pv.opt }}$ & $\mathrm{C}_{\text {ba.opt }}$ & LCE \\
min \\
\hline 0 & 7.2 & 8 & 1.229 & 7.2 & 8 & 1.172 & 7.45 & 7.5 & 0.932 \\
0.01 & 6.25 & 6.85 & 1.064 & 6.15 & 7.1 & 1.013 & 6.4 & 6.6 & 0.810 \\
0.02 & 5.6 & 6.45 & 0.970 & 5.5 & 6.7 & 0.922 & 5.7 & 6.25 & 0.741 \\
0.03 & 5.2 & 6.05 & 0.904 & 5.1 & 6.3 & 0.860 & 5.25 & 5.95 & 0.693 \\
0.04 & 4.8 & 5.95 & 0.854 & 4.8 & 5.95 & 0.811 & 5 & 5.55 & 0.655 \\
0.05 & 4.5 & 5.8 & 0.813 & 4.5 & 5.8 & 0.771 & 4.75 & 5.3 & 0.625 \\
0.06 & 4.3 & 5.55 & 0.778 & 4.3 & 5.55 & 0.739 & 4.5 & 5.15 & 0.600 \\
0.07 & 4.1 & 5.4 & 0.749 & 4.1 & 5.4 & 0.710 & 4.3 & 5 & 0.578 \\
0.08 & 3.95 & 5.2 & 0.723 & 3.95 & 5.2 & 0.685 & 4.05 & 5 & 0.560 \\
0.09 & 3.8 & 5.05 & 0.699 & 3.8 & 5.05 & 0.663 & 3.8 & 5.05 & 0.545 \\
0.1 & 3.6 & 5.1 & 0.679 & 3.6 & 5.1 & 0.642 & 3.9 & 4.55 & 0.529 \\
0.2 & 2.8 & 3.75 & 0.530 & 2.8 & 3.75 & 0.503 & 2.9 & 3.55 & 0.414 \\
0.3 & 2.1 & 3.25 & 0.434 & 2.1 & 3.25 & 0.411 & 2.2 & 3.05 & 0.346 \\
0.5 & 1.45 & 1.65 & 0.299 & 1.45 & 1.65 & 0.288 & 1.6 & 1.35 & 0.237 \\
0.8 & 0.5 & 0 & 0.137 & 0.5 & 0 & 0.137 & 0.5 & 0 & 0.117 \\
\hline
\end{tabular}

\section{REFERENCES}

[1]. M. Iqbalb, M. Azam, M. Naeem, A. S. Khwaja, and A. Anpalagan, "Optimization classification, algorithms and tools for renewable energy: A review," Renewable and Sustainable Energy Reviews, vol. 39, pp. 640654, 2014.

[2]. T. T. H. Nguyen, T. Nakayama, and $M$. Ishida, "Power Control Method Using Kalman Filter Prediction for Stable Operation of PV/FC/LiB Hybrid Power System Based on Experimental Dynamic Characteristics," Journal of the Japan Institute of Energy, vol. 94, pp. 532-541, 2015.

[3]. A. R. De, and L. Musgrove, "The optimization of hybrid energy conversion systems using the dynamic programming model," International Journal of Energy Research, vol. 12, pp. 447457, 1988.

[4]. B. S. Borowy, and Z. M. Salameh, "Methodology for optimally sizing the combination of a battery bank and PV array in a wind/PV hybrid system," IEEE Transactions on Energy Conversion, vol. 11, no. 2, pp. 367-373, 1996.
[5]. S. H.Karaki, R. B. Chedid, and R. Ramadan, "Probabilistic performance assessment of autonomous solar - wind energy conversion systems," IEEE Transactions on Energy Conversion, vol. 14, no. 3, pp. 766-772, 1999.

[6]. H. X. Yang, L. Lu, and W. Zhou, "A novel optimization sizing model for hybrid solar wind power generation system," Solar Energy, vol. 81, no. 1, pp. 76-84, 2007.

[7]. A. K. Kaviani, G. H. Riahy, and S. H. M. Kouhsari, "Optimal design of a reliable hydrogen-based stand-alone wind/PV generating system, considering component outages," Renewable Energy, vol. 34, pp. 2380-2390, 2009.

[8]. T. H. T. Nguyen, "Develop an Empirical Formula for Grid Dependency of a PV/Battery System in Vietnam using Autoregressive Model," Journal of Science and Technology, vol. 129, pp. 06-10, 2018.

[9]. H. Kakigano, Y. Miura, T. Ise, and R. Uchida, "A DC micro-grid for superhigh-quality electric power distribution," Electrical Engineering in Japan, vol. 164, pp. 34-42, 2008. 